\title{
Heat evolution due to cement hydration in foamed concrete
}

\author{
A.S. Tarasov*; E.P. Kearsley*; A.S. Kolomatskiy†; H.F. Mostert* \\ University of Pretoria; Belgorod Shukhov State Technological University; Institute of Concrete Technology \\ * Department of Civil Engineering, University of Pretoria, Pretoria 0002, South Africa \\ $\uparrow$ Belgorod Shukhov State Technological University, Russia
}

\begin{abstract}
Foamed concrete is nowadays considered an attractive building material as a result of flexible production technology and excellent target properties, along with economic benefits. Heat generated in foamed concrete during cement hydration is found to differ significantly from normal-weight concrete. Foamed concrete that is placed in a regular-shaped well-insulated mould experiences significant core temperature rises and, although several documents discussing the thermal effect in foamed concrete have been published, there is still a lack of information revealing the interrelations of foamed concrete parameters and their effect on temperature rise. Laboratory tests were carried out with foamed concrete of variable densities and volumes under semi-adiabatic curing conditions. The observed trends were used as the initial input for a mathematical model of temperature prediction in foamed concrete. The heat evolution process under real production conditions can be controlled by optimising the mix composition. If the thermal energy in foamed concrete is properly employed it can result in considerable improvement of the final product characteristics while production costs decrease.
\end{abstract}

\section{NOTATION}

$A$ overall surface area of foamed concrete cube in a sealed box $\left(\mathrm{m}^{2}\right)$

$a / c$ ash/cement ratio

Cem cement content in foamed concrete $\left(\mathrm{kg} / \mathrm{m}^{3}\right)$

$C_{\mathrm{v}}$ volumetric heat capacity of foamed concrete $\left(\mathrm{kJ} /\left(\mathrm{m}^{3}{ }^{\circ} \mathrm{C}\right)\right)$

$c_{i}$ specific mass heat capacities of components (cement, filler, water, foaming agent and the air) $(\mathrm{J} /(\mathrm{kg}$ $\left.{ }^{\circ} \mathrm{C}\right)$ )

$D$ design dry density of hardened foamed concrete $\left(\mathrm{kg} / \mathrm{m}^{3}\right)$

$F$ sum of the weights of filler content in foamed concrete (ash and/or silica sand etc.) $\left(\mathrm{kg} / \mathrm{m}^{3}\right)$

$m_{i}$ mass content of the ingredients in foamed concrete as it is prescribed in mix compositions $\left(\mathrm{kg} / \mathrm{m}^{3}\right)$

$R D_{\text {c }}$ relative density of cement 
$R D_{\text {a }}$ relative density of ash

$R D_{\mathrm{s}}$ relative density of sand

$S$ mass of all solid ingredients in the given foamed concrete mix $\left(\mathrm{kg} / \mathrm{m}^{3}\right)$

$s / c$ sand/cement ratio

$w / c$ water/cement ratio

$V$ volume of foamed concrete in a sealed box $\left(\mathrm{m}^{3}\right)$

$V_{f}$ volume of foam (1)

$\lambda_{i}$ thermal conductivity of constituents (cement, filler, water, foaming agent and the air) $(\mathrm{W} /(\mathrm{m} \mathrm{K}))$

$\lambda_{\mathrm{v}}$ thermal conductivity values for foamed concrete mixes $(\mathrm{W} /(\mathrm{m} \mathrm{K})$ )

$\rho_{i}$ real density of a constituent in the mix $\left(\mathrm{kg} / \mathrm{m}^{3}\right)$

$\rho_{\mathrm{v}}$ casting density of foamed concrete $\left(\mathrm{kg} / \mathrm{m}^{3}\right)$

\section{INTRODUCTION}

Foamed concrete is a versatile material which has become widely used in the construction industry, mostly for cast-in-situ applications in roof slopes, floor levelling and insulating layers of wall constructions, as well as for any kind of void filling (mines, tunnels, road basements, ground stabilisation, land reclamation and others), owing to its free-flowing properties, excellent heat-insulating characteristics, low density and affordable strength values. In this case dry densities of $300-500 \mathrm{~kg} / \mathrm{m}^{3}$ are normally applied as there are no strict requirements to strength characteristics, and thermal conductivity plays the more dominant role (Aldridge, 2000; 2005; Basuirski and Wells, 2001; Cox and Van Dijk, 2003; Giannakou, 2002; Jones and McCarthy, 2005b; Kearsley and Mostert, 2005b; Tisyachuk and Svinarev, 2005; Vasiljev and Lundyshev, 2003; Wimpenny, 1996).

Foamed concrete has also found its application as an alternative to autoclaved aerated concrete (AAC) products for semi-structural purposes, especially where small-capacity production facilities are more economically efficient as foamed concrete plants require much lower capital expenditures owing to the simplicity of the technology in comparison with AAC factories (Tarasov et al., 2005). In this case the most common dry density range lies within $500-900 \mathrm{~kg} / \mathrm{m}^{3}$ as both compressive strength and insulating properties of the foamed concrete need to meet standard requirements. The most progressive technologies for the manufacture of foamed concrete products include high-volume mass castings with subsequent cutting of the green concrete into products with given dimensions (Kolomatskiy, 2003).

Hence, both cast-in-situ and product items entail high volumes of foamed concrete to be poured in one section, which may lead to a significant rise in core temperature owing to the heat of cement hydration (Jones and McCarthy, 2006; Kolomatskiy, 2003; Tarasov et al., 2005; Tarasov, 2007). Although several documents discussing the thermal effect in foamed concrete have been published, there is still a lack of information revealing the interrelations of foamed concrete parameters and their effect on temperature rise (Jones and McCarthy, 2006; Sakharov, 2002). 
The main goal of the present study is to investigate the influence of foamed concrete density, volume of casting and fine aggregate type on temperature profiles that can develop in foamed concrete due to cement hydration. Thermal gradients between core and surface of foamed concrete specimen were also registered to estimate the risk of cracking. An attempt was made to create a prediction model for temperature development in foamed concretes.

\section{PARAMETERS INFLUENCING HEAT EVOLUTION IN FOAMED CONCRETE}

Heat evolution in foamed concrete is affected by a greater number of parameters than normal-weight concretes (Jones and McCarthy, 2006). Results have been published to indicate the significance of the parameters influencing the temperature development of foamed concrete (Jones and McCarthy, 2006). The factors affecting heat evolution of cement in foamed concrete can be divided into two main groups, namely foamed concrete internal parameters and outside environmental factors, as described below.

Internal foamed concrete parameters

(a) characteristics of the cement

(i) volume of cement per cubic metre of foamed concrete

(ii) mineralogical composition of cement clinker and cement fineness

(b) water/cement ratio

(c) heat capacity of 1 cubic metre of foamed concrete

(i) foamed concrete density

(ii) type and amount of aggregate

(d) initial temperature of foamed concrete mix

(e) size of foamed concrete mix pouring

$(f)$ pore size, distribution and connectivity.

Environmental factors

(a) insulation

(b) parameters of the outside environment (air temperature and humidity, air velocity)

(c) other external influences (pressure, heating, different types of rays etc.).

Both types of concrete (normal-weight and foamed concrete) comprise solid, liquid and gaseous phases, but the latter phase is dominant (up to $70 \%$ by volume) in the cellular concrete. The gaseous phase (which in foamed concrete is normally presented by the air) acts as a heat insulator, preventing heat dissipation. The evolved heat is transferred mostly through interporous partitions by means of heat conductivity. It has been shown (Anikanova, 2007) that in cellular concrete, especially low-density concretes, the heat is also 
transferred through the heat boundary layer that is formed between a pore and interporous partition, while convection is negligible.

The rate of hydration is faster for finer cement, higher initial temperature of mix and higher water/cement ratios (Bentz, 1998; De Schutter and Taerwe, 1995). These factors were not investigated in this project.

Temperature development in cellular concrete containing Portland cement seems to be influenced mostly by density and pouring size, with the other factors being comparable to normal-weight concrete. The influence of cement content and fly ash as fine aggregate on temperature profiles is, however, unclear.

\section{EXPERIMENTAL SET-UP}

The aim of the laboratory investigation was to determine the effect of foamed concrete density and pour size on the temperature profiles. Temperature development in foamed concrete subjected to semiadiabatic conditions in insulated boxes was measured.

The cement used in the investigation is Portland cement (denoted PC) with a density of $3140 \mathrm{~kg} / \mathrm{m}^{3}$, which can be classified as a CEM I $42.5 \mathrm{R}$ according to the South African specification SANS 50197$1: 2000$ (SABS, 2002). The fly ash, with a density of $2200 \mathrm{~kg} / \mathrm{m}^{3}$, is an unclassified ash where approximately $40 \%$ of the particles have a particle size exceeding $45 \mu \mathrm{m}$. The chemical composition of the cement and the ash can be seen in Table 1. The foaming agent consists of hydrolysed proteins and is diluted with water to a $2 \%$ concentration and then aerated to form foam with a density of $75 \mathrm{~kg} / \mathrm{m}^{3}$.

\section{Table 1. Chemical composition of Portland cement and fly ash}

\begin{tabular}{l|c|c}
\hline Main oxides & Portland cement:*\% & Fly ash: \% \\
\hline $\mathrm{CaO}$ & $61 \cdot 7$ & $5 \cdot 0$ \\
$\mathrm{SiO}_{2}$ & $21 \cdot 2$ & $54 \cdot 8$ \\
$\mathrm{Al}_{2} \mathrm{O}_{3}$ & $4 \cdot 6$ & $31 \cdot 7$ \\
$\mathrm{Fe}_{2} \mathrm{O}_{3}$ & $1 \cdot 8$ & $3 \cdot 8$ \\
$\mathrm{Na}_{2} \mathrm{O}$ & $0 \cdot 1$ & $0 \cdot 8$ \\
$\mathrm{~K}_{2} \mathrm{O}$ & $0 \cdot 7$ & $0 \cdot 8$ \\
$\mathrm{MgO}_{\mathrm{SO}}$ & $4 \cdot 3$ & $1 \cdot 1$ \\
$\mathrm{SO}_{3}$ & $2 \cdot 0$ & $0 \cdot 3$ \\
Loss on ignition & $0 \cdot 8$ & $0 \cdot 8$ \\
\hline
\end{tabular}

* Phase composition: $\mathrm{C}_{3} \mathrm{~S}=45 \cdot 8 \%, \mathrm{C}_{2} \mathrm{~S}=26 \cdot 2 \%, \quad \mathrm{C}_{3} \mathrm{~A}=9 \cdot 2 \%$, $\mathrm{C}_{4} \mathrm{AF}=5 \cdot 5 \%$.

A density grade $(D)$ was used to calculate the foamed concrete mix composition. This density grade is the design dry density of cellular concrete (Tarasov et al., 2005) stipulated in Russian standard GOST 2548589 (Gosstandart, 1990). The dry densities of foamed concrete were chosen in the range D400-D1200 with silica sand as fine aggregate and D400-D800 with fly ash as fine aggregate. These are the dry densities, which are commonly used in the construction industry. The effect of Portland cement content was 
established while varying the dry densities from D250 to D650 without using any fine aggregate. It was assumed that the water bound in the chemical hydration reactions will result in the addition of $20 \%$ to the mass of the unhydrated cement, while assuming that fly ash plays the sole role of a filler and no amounts of fly ash are hydrated (Kearsley, 1999; Kearsley and Mostert, 2005a; Tarasov et al., 2005). Although the fly ash will start taking part in the hydration process, the rate of reaction is a function of temperature and to simplify the modelling process this variable was not included in the current study. The following equation was produced

$D=1 \cdot 2 \mathrm{Cem}+F$

where $D$ is the design dry density of hardened foamed concrete $\left(\mathrm{kg} / \mathrm{m}^{3}\right)$, Cem is the cement content $\left(\mathrm{kg} / \mathrm{m}^{3}\right)$ and $F$ is the sum of the weights of filler content in foamed concrete (ash and/or silica sand, etc.) $\left(\mathrm{kg} / \mathrm{m}^{3}\right)$.

Besides the dry density formula (see Equation 1), the sum of the volume of all the constituent materials should be 1 cubic metre (or 1000 litres) (Kearsley, 1999; Kearsley and Mostert, 2005a; Kearsley and Wainwright, 2001) as shown in the formula below

$$
1000=\frac{x}{R D_{\mathrm{c}}}+x(w / c)+\frac{x(a / c)}{R D_{\mathrm{a}}}+\frac{x(s / c)}{R D_{\mathrm{s}}}+V_{\mathrm{f}}
$$

where $x$ is the cement content $\left(\mathrm{kg} / \mathrm{m}^{3}\right) ; w / c$ is the water/cement ratio (indicating total water to cement mass in the foamed concrete mix); $a / c$ is the ash/cement ratio; $s / c$ is the sand/cement ratio; $V_{\mathrm{f}}$ is the volume of foam (1); $R D_{\mathrm{c}}$ is the relative density of cement; $R D_{\mathrm{a}}$ is the relative density of ash; and $R D_{\mathrm{s}}$ is the relative density of sand.

The calculation of foamed concrete mix compositions can be seen in Table 2 and Table 3 . In Table 2 the cement content was kept constant for different mix compositions in order to look into the influence of foamed concrete density and pour size on temperature development. In the mixtures presented in Table 3, the cement content varied for foamed concrete of different densities while the water/cement ratio was kept constant and no fine aggregates were incorporated into the mixes.

Foamed concrete mixes were produced using preformed foam and mortar slurry mixed in a rotary drum mixer with a horizontal main shaft. The foam was generated by diluting a hydrolysed protein-based foaming agent with water to a $2 \%$ concentration and then blending in compressed air until the foam had a density of $75 \mathrm{~kg} / \mathrm{m}^{3}$. As soon as the homogeneous mortar was prepared, the preformed foam was added and incorporated. The plastic density of the foamed concrete mix was measured with a tolerance of \pm 50 $\mathrm{kg} / \mathrm{m}^{3}$.

The foamed concrete was then poured into specially prepared insulated cubic moulds of different sizes with side lengths of 100, 400 and $800 \mathrm{~mm}$. The 'hot curing' boxes were constructed with $100 \mathrm{~mm}$ thick polystyrene sheets covered by $15 \mathrm{~mm}$ plywood boards reinforced with wooden beams. Once the box was filled with foamed concrete, it was levelled by trowel and covered with a polystyrene sheet and plywood on top. K-type thermocouples were placed into the centre and surface of each foamed concrete mass using copper tubes filled with synthetic oil. The layout and illustration of the experimental set-up is shown in Figure 1. 
The temperature development caused by heat of cement hydration in foamed concrete was recorded using a Graphtec GL 400/350 Midi Logger (Graphtec Corporation, Japan). The data were captured at 10 min intervals. Afterwards all received data were transferred to computers and processed to obtain final temperature profiles.

\section{Table 2. Foamed concrete mix compositions with fly ash/silica sand* (constant PC content)}

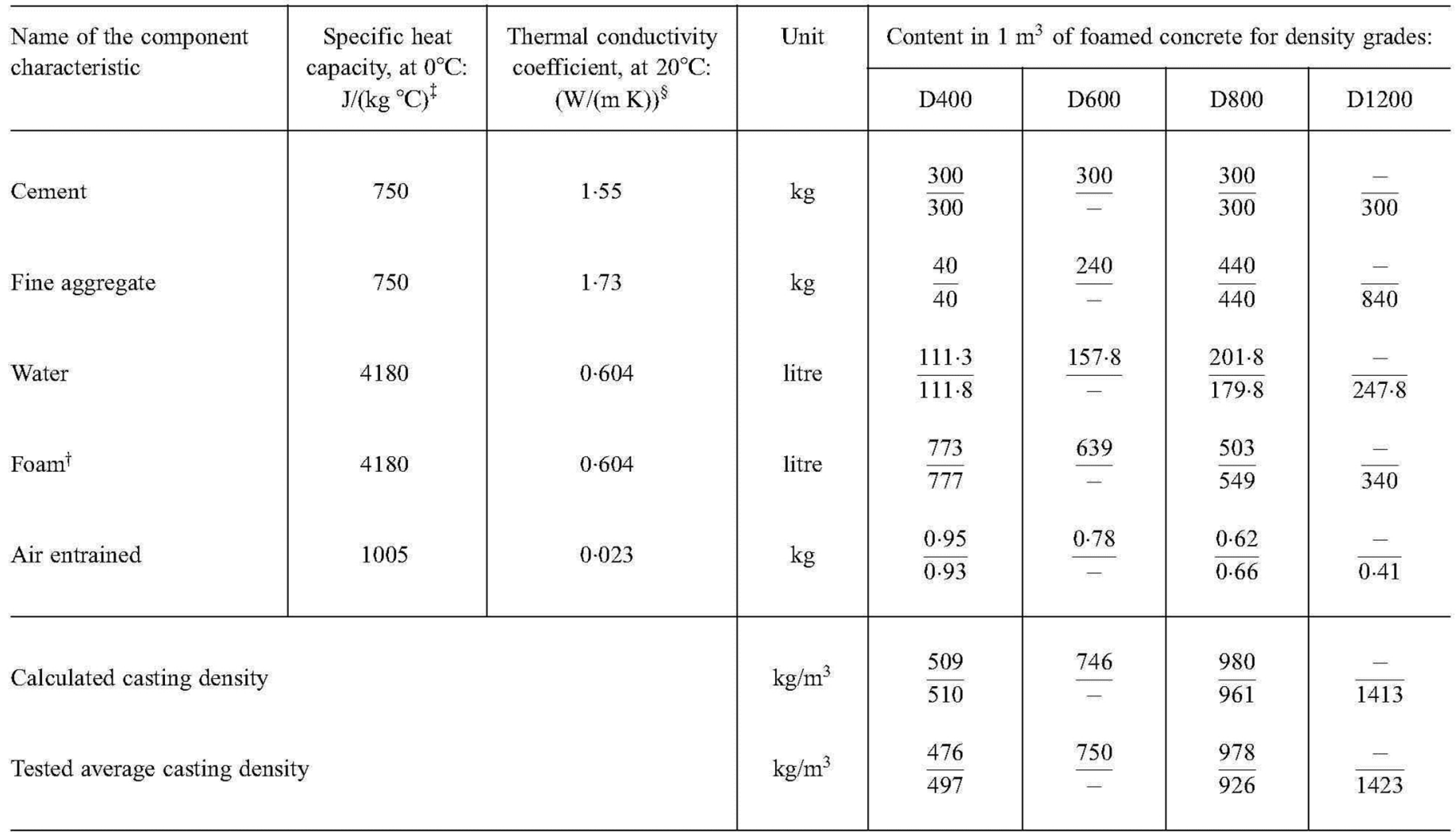

* Upper values in the table correspond to mixes with fly ash, and lower values with silica sand.

$\dagger$ Heat conductivity and heat capacity values valid for foamed concentrate are assumed to be the same as water parameters.

${ }^{\ddagger}$ Bentz, 1998; De Schutter and Taerwe, 1995; Springenschmid, 1998.

$\S$ Bentz, 1998, 2007; De Schutter and Taerwe, 1995; Kim et al. 2003; Zaporozhets et al., 1966.

Table 3. Foamed concrete mix compositions without aggregates, w/c ratio $0 \cdot 35$

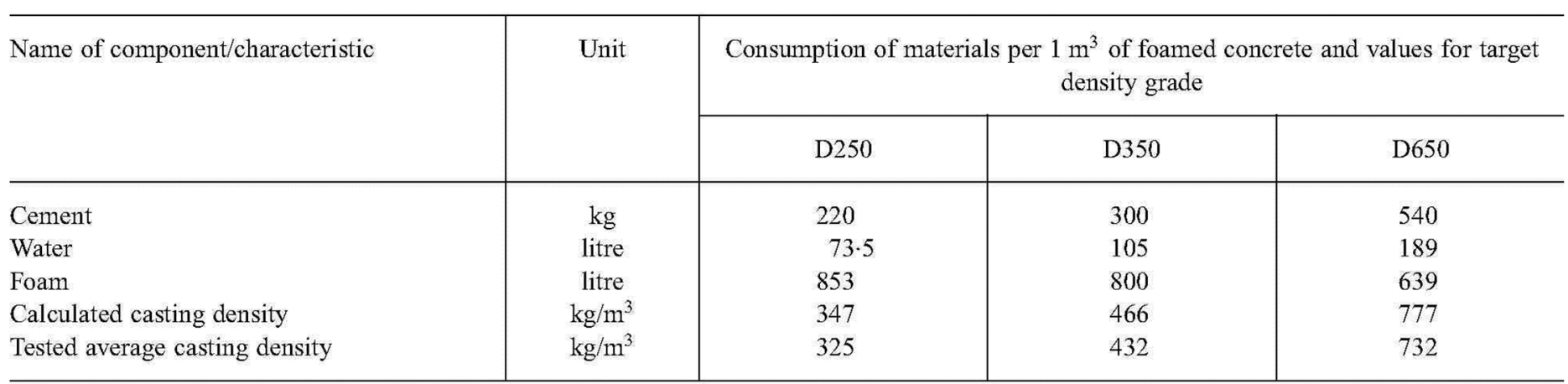




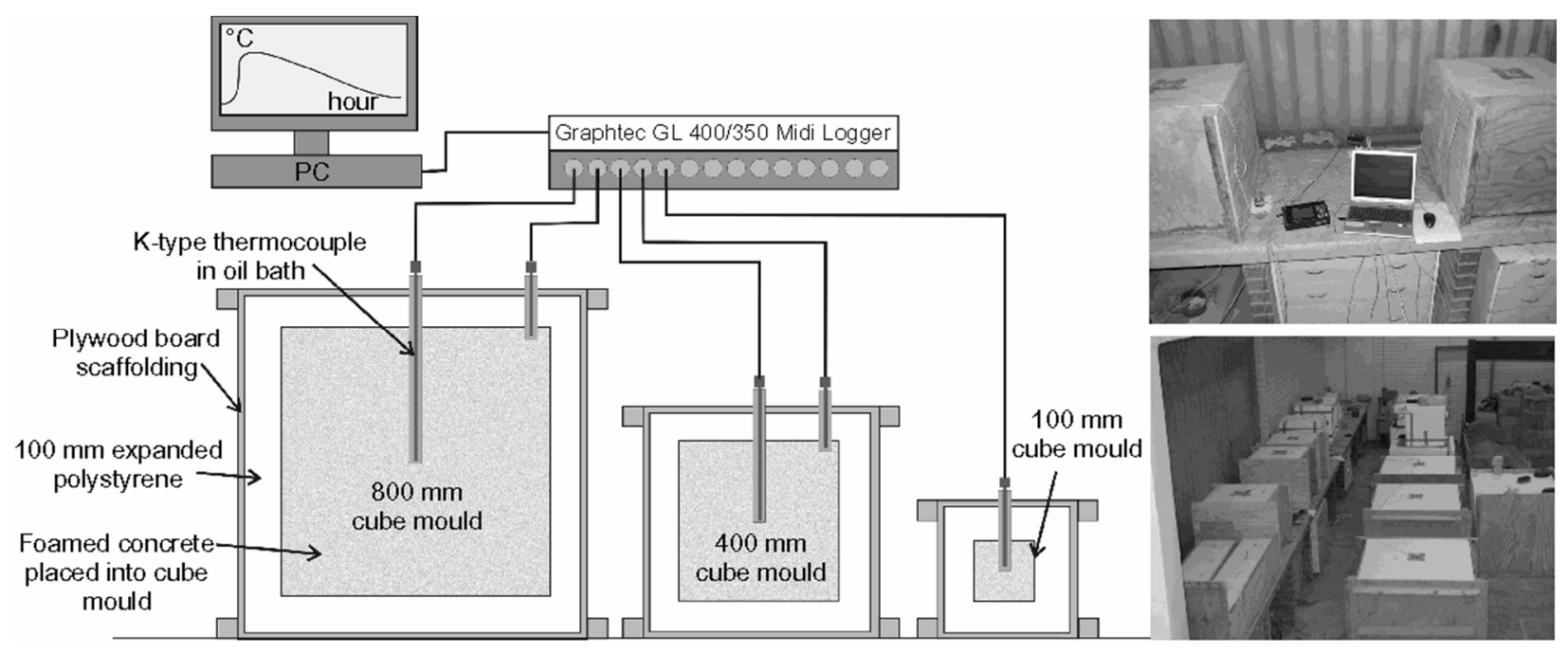

Figure 1. Layout and illustration of sealed-box foamed concrete curing test

\section{EXPERIMENTAL RESULTS}

\section{Temperature profiles}

The effect of foamed concrete density and pour size was examined with the mixes as shown in Table 2 (keeping the cement content constant). Dry densities of foamed concrete with fly ash varied from D400 to D800, and with sand varied from D400 to D1200. The temperature profiles obtained are given in Figure 2 and Figure 3, for fly ash and silica sand as fine aggregates, respectively.

Temperatures inside the $800 \mathrm{~mm}$ and $400 \mathrm{~mm}$ cubes reached their maximums within $12-18 \mathrm{~h}$ from casting. Peak temperature values in the $800 \mathrm{~mm}$ cubes are $1 \cdot 75-2 \cdot 25$ times higher than in $100 \mathrm{~mm}$ cubes for fly ash, and $2 \cdot 05-2 \cdot 15$ times for those with silica sand, depending on the foamed concrete density. Foamed concrete in $400 \mathrm{~mm}$ cubes evolves much more heat in comparison with $100 \mathrm{~mm}$ cubes, and the margins of the registered temperatures were 1.7-1.95 and 1.55-1.85 times higher for fly ash and silica sand, respectively. It can be seen from these graphs that cube size drastically changes the heat evolution curves of the foamed concrete.

The other observed peculiarity of the foamed concrete heat evolution is related to the material's density. The lighter the material, the better it conserves the heat inside the mass, preventing its dissipation from the cube centre. The highest temperature values, as well as the highest rate of temperature increase, were recorded for D400 foamed concrete (the lowest density in these sets of experiments), both for fly ash and silica sand fine aggregates. This trend becomes more evident as pouring size is increased.

As soon as peak temperatures are reached the temperature starts going down as the amount of the subsequently evolved heat is no longer sufficient to maintain temperature growth. The heat continues to be consumed by constituent products and dissipated into the environment through the box insulations. The slopes of the temperature curves beyond the turning point depend on the heat-accumulating ability (thermal inertia) of the foamed concrete, which is mostly determined by the coefficient of thermal diffusivity. 


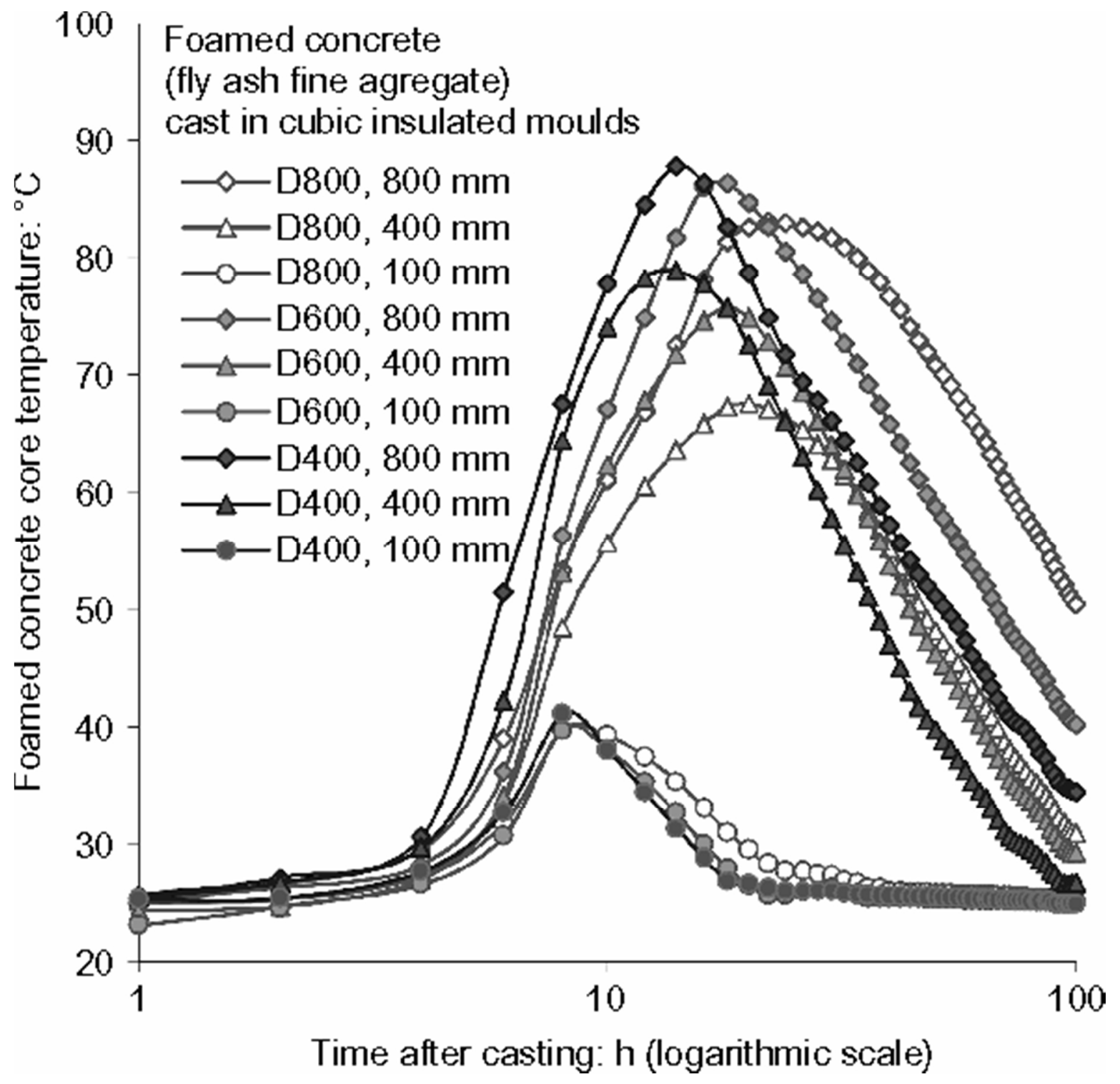

Figure 2. Influence of pour size and density on temperature profiles of foamed concrete with fly ash 


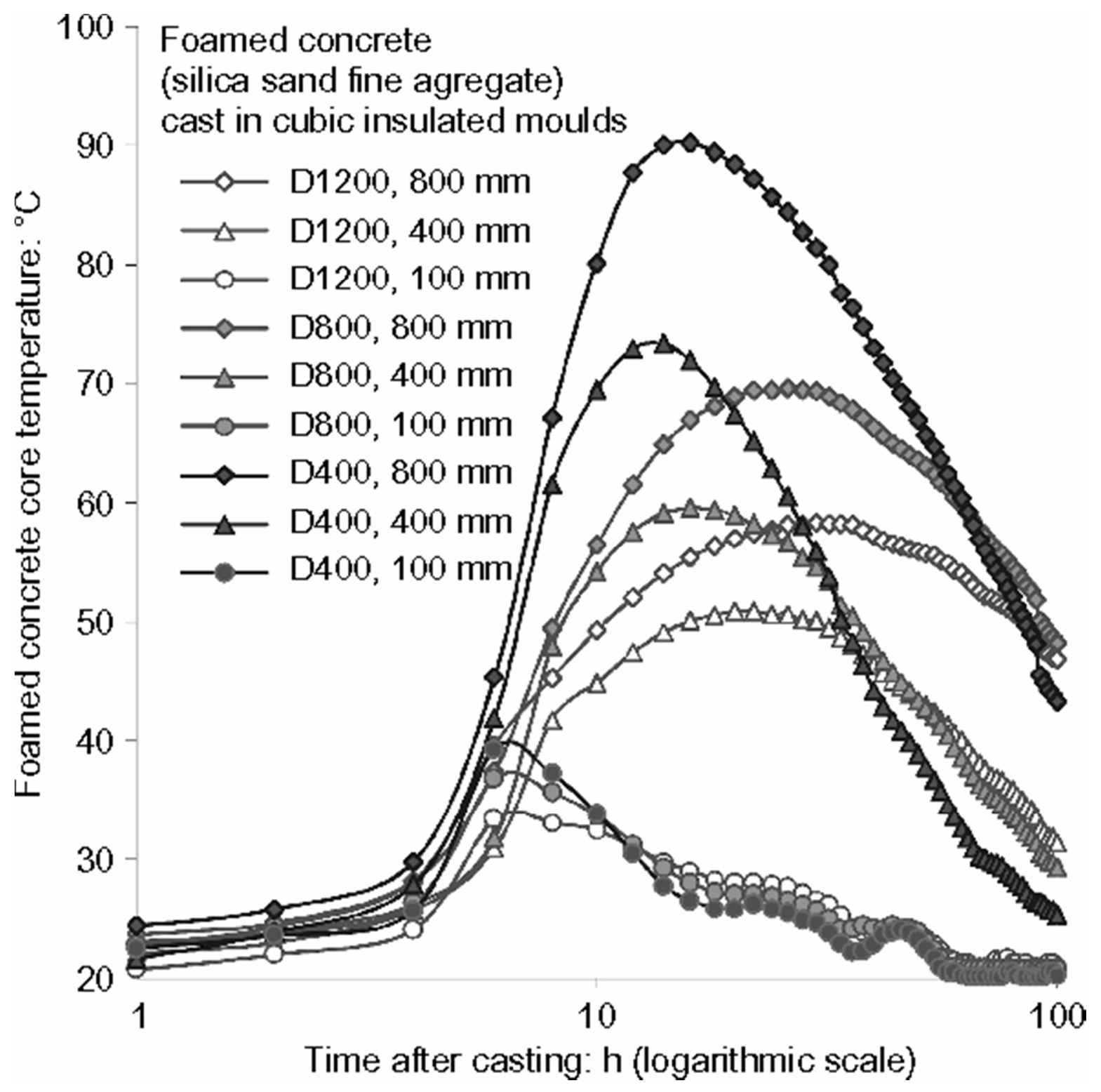

Figure 3. Influence of pour size and density on temperature profiles of foamed concrete with silica sand

The curves in Figure 4 illustrate temperature profiles for foamed concrete where the cement content is varied as shown in Table 3 . This foamed concrete contained no fine aggregate and the dry densities varied from D250 to D650. The cube sizes were the same as in the previous sets of experiments. Size effect in these mixtures had a similar influence on the temperature gradient as foamed concrete with a constant cement content. The density effect was, however, overwhelmed by cement content, which was the dominant influencing factor in these systems. 


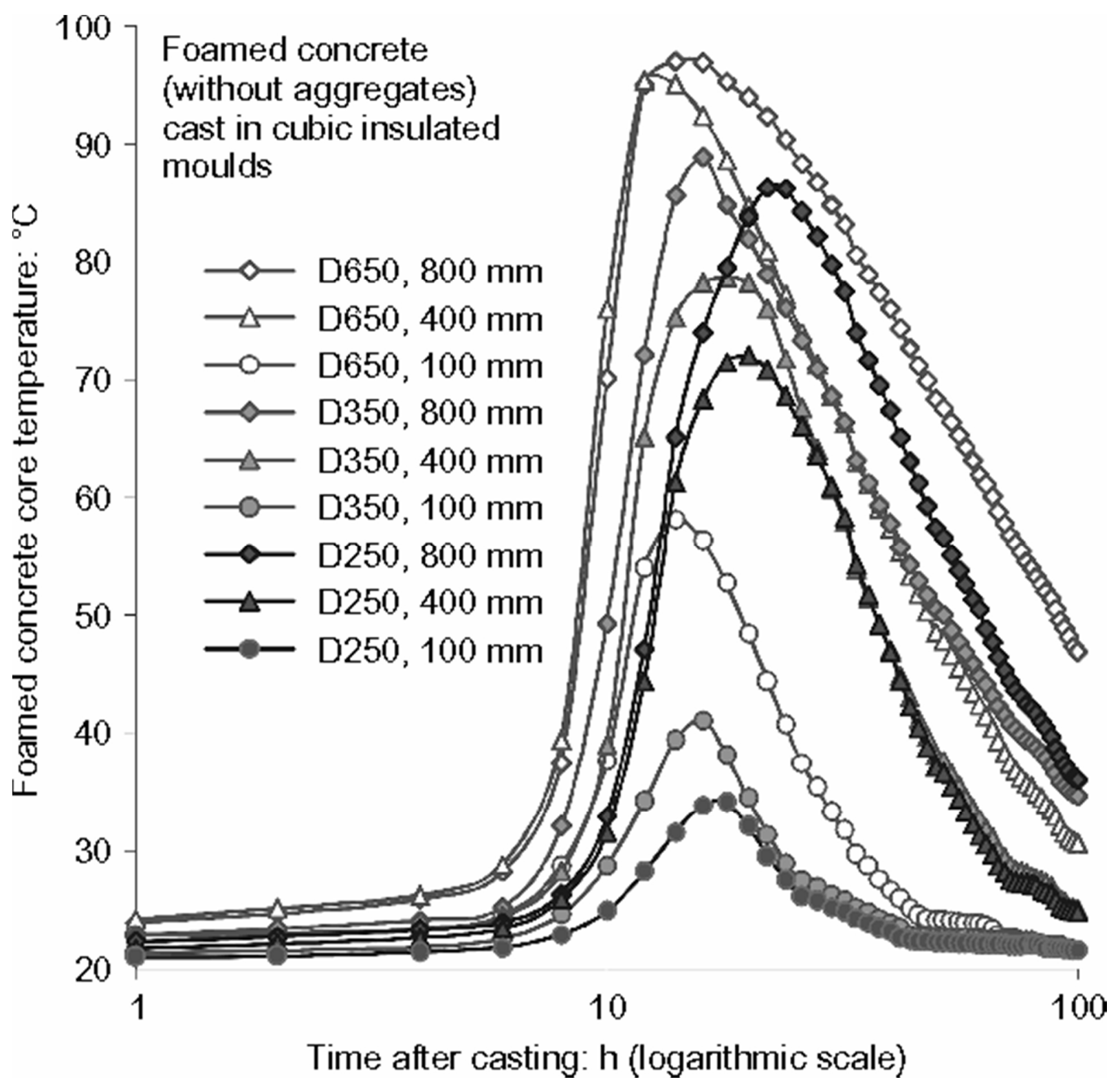

Figure 4. Temperature profiles of foamed concrete curing in sealed boxes with different cement contents

Fluctuations of temperature curves after more than 2 days following casting, especially for $100 \mathrm{~mm}$ cubes, resulted from daily room temperature variations, indicating insufficient insulation of the moulds.

It should also be noted that some temperature curves in the $800 \mathrm{~mm}$ cubes were visibly dropping quickly as they reached high temperatures. This happened because of different volumetric thermal expansion values of constituents of the foamed concrete, mostly due to air bubbles having significantly (over 100 times) higher coefficient of volumetric thermal expansion values than cement stone or (over 10 times) water at the temperature range $20-80^{\circ} \mathrm{C}$ (Malinina, 1977; Shakhova, 2007). These differences caused excessive internal stresses in the foamed concrete matrix, resulting in its collapse. The other probable reason could be protein coagulation at high temperatures that induced irrevocable destruction of the porous structure. Foamed concrete mixtures with a synthetic type of foaming agent were not investigated 
in the present paper. Nevertheless, this phenomenon has to be taken into consideration when high temperatures occur in foamed concrete.

Core-surface temperature differentials in foamed concrete masses

The temperature differentials between the core and surface of sealed cured foamed concrete with fly ash as fine aggregate were registered in the $800 \mathrm{~mm}$ and $400 \mathrm{~mm}$ cube moulds. The resulting curves are presented in Figure 5.

The initial temperature differential of $2-3^{\circ}$ disappears within the first $3 \mathrm{~h}$ after casting in low-density foamed concretes. After 3 to $4 \mathrm{~h}$ the difference starts increasing and reaches a maximum after 30 to $40 \mathrm{~h}$ in the $800 \mathrm{~mm}$ cubes. After $42 \mathrm{~h}$ the difference reaches a maximum of $21 \cdot 3^{\circ}$ for D800 foamed concrete. Afterwards the difference decreases, but after $72 \mathrm{~h}$ the temperature differences in D800 and D600 foamed concretes are still high $\left(17^{\circ}\right.$ and $9^{\circ}$ respectively). Meanwhile D400 foamed concrete has a low difference of temperatures $\left(2-4^{\circ}\right)$ for the whole registered period.

In general it can be concluded that the heavier the foamed concrete, and the bigger the size of a mould, the higher the thermal difference. Taking into the account the risk of thermal cracks occurring, lowdensity foamed concretes are preferable for use in large pours.

\section{DISCUSSION OF RESULTS}

\section{Rate of temperature development in foamed concrete}

The temperature profiles given in Figure 2 and Figure 3 have been interpreted to obtain a rate of temperature development in the centres of insulated foamed concrete $800 \mathrm{~mm}$ and $400 \mathrm{~mm}$ cubes (see Figure 6).

The peaks in the curves indicate the maximum rate of temperature rise and time of its occurrence in the centres of foamed concrete cubes. Regardless of cube size (either $800 \mathrm{~mm}$ or $400 \mathrm{~mm}$ ) all the peaks lie in the time interval between $5 \cdot 5$ and $8 \mathrm{~h}$ after casting; but for larger $(800 \mathrm{~mm})$ cubes the peaks are shifted earlier by $0 \cdot 5-1 \cdot 5 \mathrm{~h}$. Heat evolution starts accelerating earlier in larger foamed concrete cubes because foamed concrete cores are more insulated by the material itself.

Definite trends can be observed for both the magnitude and time of the peak occurrence. Lighter foamed concretes always show higher rates of temperature rise due to less heat capacity in comparison with heavier foamed concretes. Considering similar densities in $800 \mathrm{~mm}$ cubes, foamed concrete with fly ash shows a higher rate of temperature rise than that with silica sand. The D800 foamed concrete with silica sand in $400 \mathrm{~mm}$ cubes was the only specimen with an unexpected rate of heat development.

The maximum temperature is reached when the rate of heat development becomes negative, as can be seen in Figure 6 (b). The heavier the foamed concrete, the more time it required to get to the maximum temperature regardless of the type of aggregate. It is also noted that it takes more time for higher volumes of material ( $800 \mathrm{~mm}$ cubes) to heat up to maximum than for smaller volumes ( $400 \mathrm{~mm}$ cubes). However, foamed concrete with fly ash reaches the peak temperatures earlier than that with silica sand. 

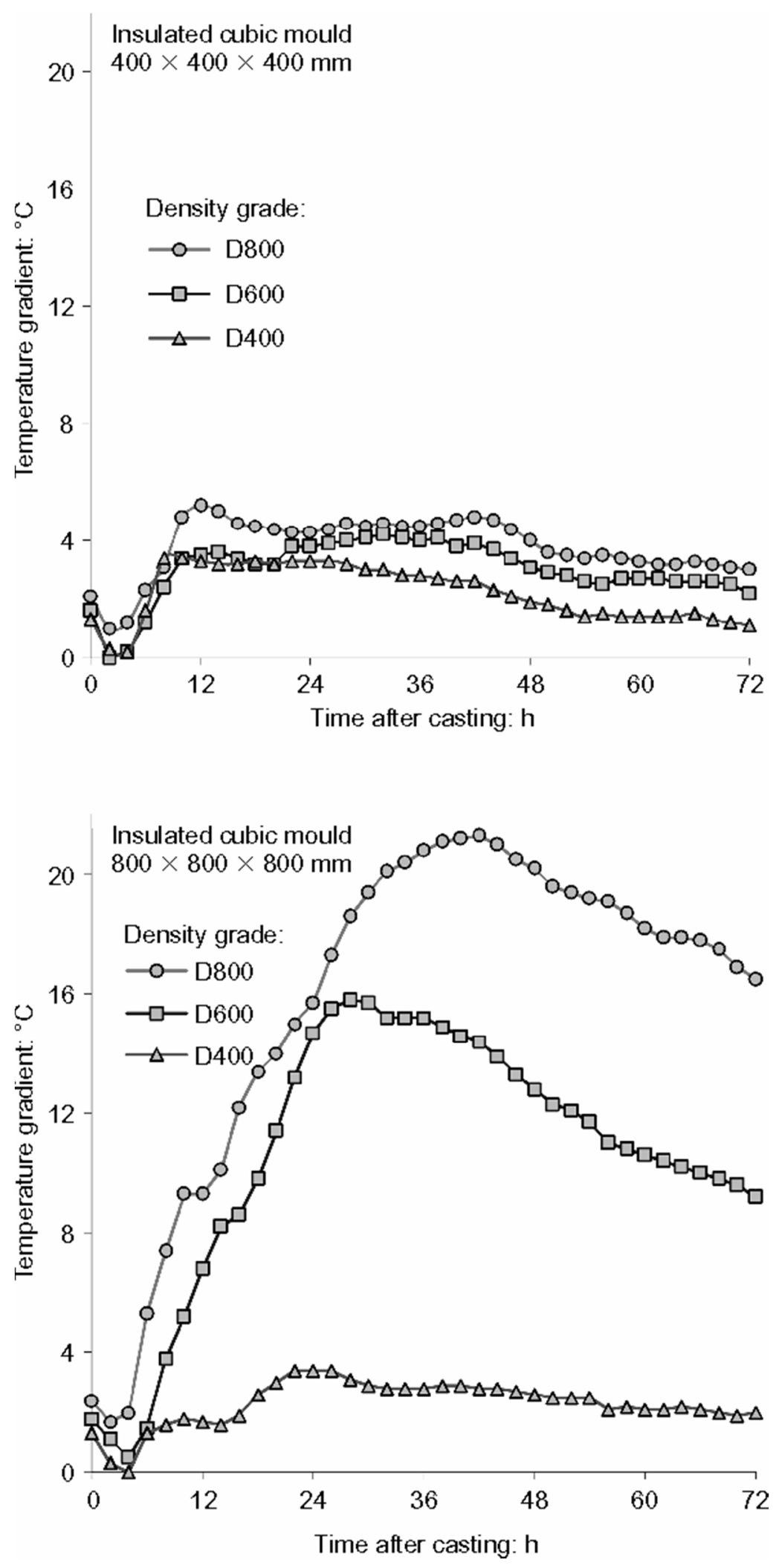

Figure 5. Influence of density and mould size on core-surface temperature differentials in foamed concrete (fly ash fine aggregate) 

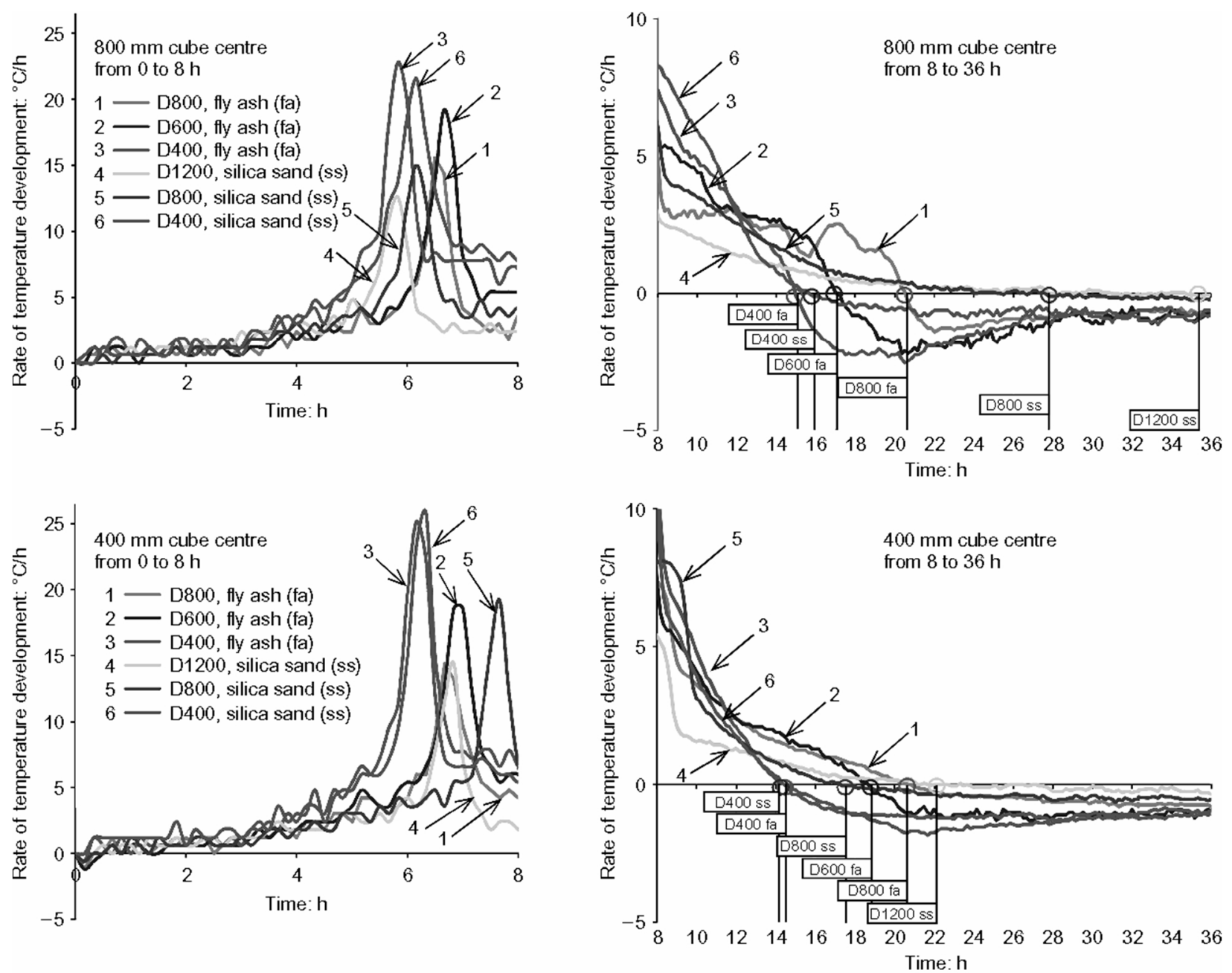

(a)

(b)

Figure 6. Rate of temperature development in foamed concrete cores of $800 \mathrm{~mm}$ and $400 \mathrm{~mm}$ sealed cubes

\section{Effect of aggregate type and cement content on temperature profiles}

The experimental programme of the present study allowed investigation of the influence of aggregate type on heat evolution in foamed concrete. The literature proves (Atis, 2002; Jones and McCarthy, 2005;

Kearsleyand Wainwright, 2001) that the replacement of a part of cement with fly ash is beneficial, such as in the reduction of core temperatures and crack development, long-term strength improvement and so on. Fly ash can also be used as fine aggregate in foamed concrete but this should logically increase the total generated heat. However, Jones and McCarthy (2006)) report that replacement of sand with fly ash as fine aggregate led to a reduction of temperature, although heat capacities of the aggregates are similar (from 700 to $\left.800 \mathrm{~J} / \mathrm{kg}{ }^{\circ} \mathrm{C}\right)$, while it is significantly less than the heat capacity of water $\left(4180 \mathrm{~J} / \mathrm{kg}{ }^{\circ} \mathrm{C}\right)$. The authors explained that the higher water content in the mixes with fly ash means a greater amount of energy is required to produce a temperature increment. Langan et al. (2002) reported that fly ash increases initial hydration but retards the dormant and acceleration periods. It also accelerates hydration after the acceleration period. 
The test results of the current investigation (see Figure 7) indicate that fly ash contributes towards the temperature effect in foamed concrete. Comparing identical densities (D400, D800) and pouring volumes $(100,400,800)$, foamed concrete with fly ash showed a higher rate (see Figure 6) and maximum values of temperature development than foamed concrete with silica sand (see Figure 7), regardless of water consumption.

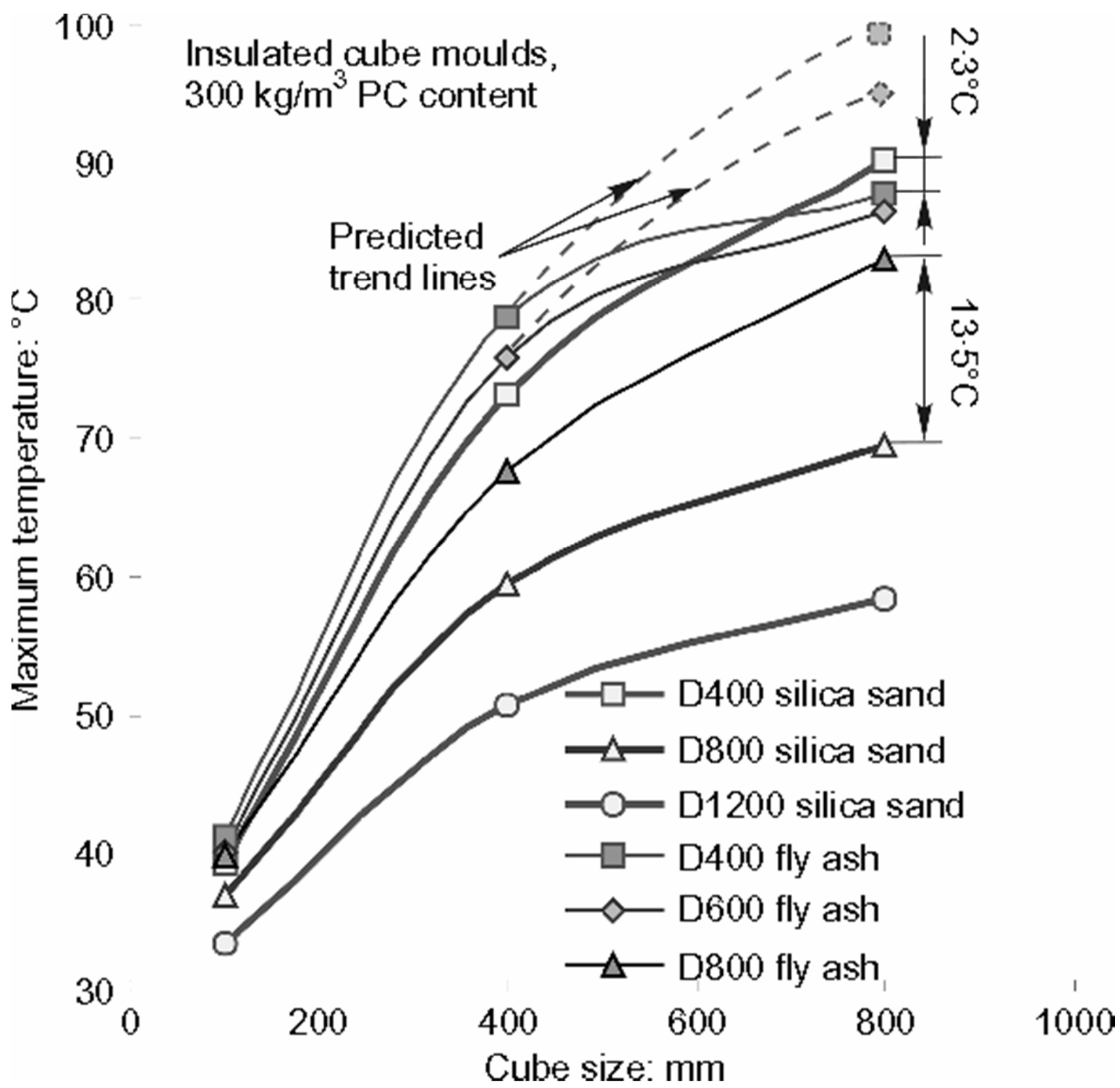

Figure 7. Effect of aggregate type on maximum temperature rise in foamed concrete

It is interesting to note that for the same cube size the difference between fly ash and silica sand foamed concrete is higher for D800 than for D400 because of larger amounts of fly ash introduced into the mix to obtain higher density. This confirms that fly ash contributes to heat evolution and that chemical reactions are being activated at elevated temperatures. The dotted trend lines in Figure 7 illustrate the prognosed temperature development in extra lightweight foamed concretes at cube sizes over $400 \mathrm{~mm}$. These types of foamed concrete could not practically reach their expected maximums due to extreme (close-toboiling) temperatures leading to structural collapse and large heat losses. 
Cement content has an impact on temperature development in foamed concrete under semi-adiabatic conditions, as shown in Figure $\underline{8}$. There is a near-linear relationship between cement content and maximum temperature recorded in foamed concrete of $100 \mathrm{~mm}$ and $400 \mathrm{~mm}$ cube size, and only one point for the highest cement content and biggest cube size $(800 \mathrm{~mm})$ falls out of the relationship, owing to the inability of the foamed concrete structure to bear such internal temperature- and moisture-derived stresses, resulting in cellular skeleton destruction and heat energy release from the foamed concrete core. The trend line shows that a temperature over $100^{\circ} \mathrm{C}$ should have been reached hypothetically if total energy potential is used without any side effects. For the specific laboratory conditions it was established that every $100 \mathrm{~kg}$ of cement added to the initial cement content of $220 \mathrm{~kg} / \mathrm{m}^{3}$ produces a temperature increase of $7 \cdot 4^{\circ} \mathrm{C}$.

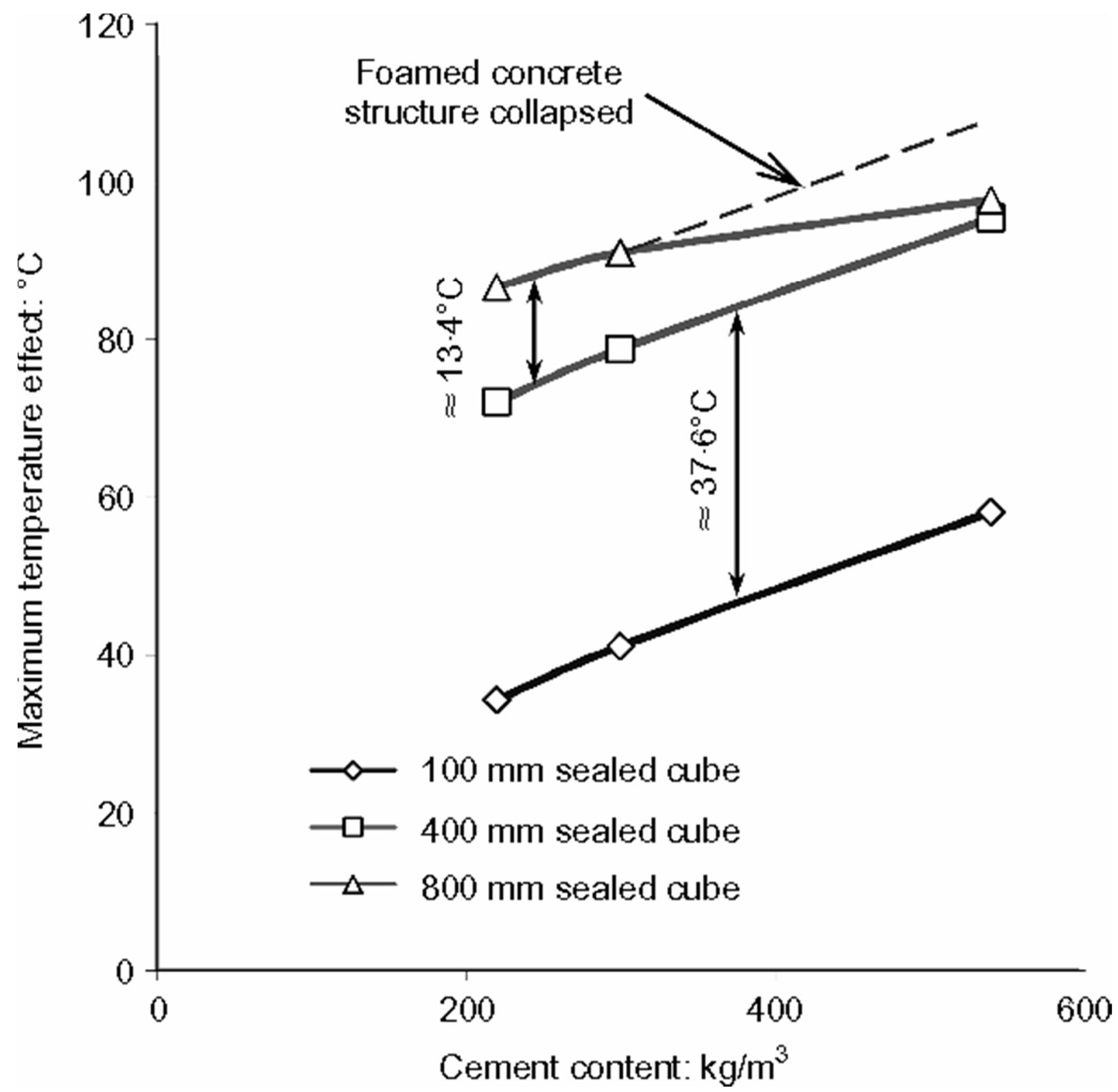

Figure 8. Effect of cement content on maximum temperature rise in foamed concrete 


\section{Effect of foaming agent on the kinetics of cement heat evolution}

Foam is a two-phase system where air bubbles are surrounded by liquid films. The liquid phase consists of foam concentrate dissolved in water. Depending on the foamed concrete technology applied, the foam concentrate may be incorporated either by mixing all the components in a blending mixer or by adding foam into cement slurry. In any case, foam substance is present in the water-cement hardening system, and as soon as the foam is no longer required in its functional role of porous structure former, it starts to retard cement hydration.

Preliminary calorimetric studies have been conducted to evaluate the rate of heat evolution of cement hydration in the presence of foaming agent during a $72 \mathrm{~h}$ period of interaction. The limited study was conducted on a small scale and further investigations will be required.

A sample of $2 \mathrm{~g}$ of cement was taken and mixed with $2 \mathrm{~g}$ of water or water containing foaming agent. The percentages of foaming agent were $0 \cdot 04,0 \cdot 2,1 \cdot 0 \%$ of cement mass. The results of the tests are shown in Figure 9.

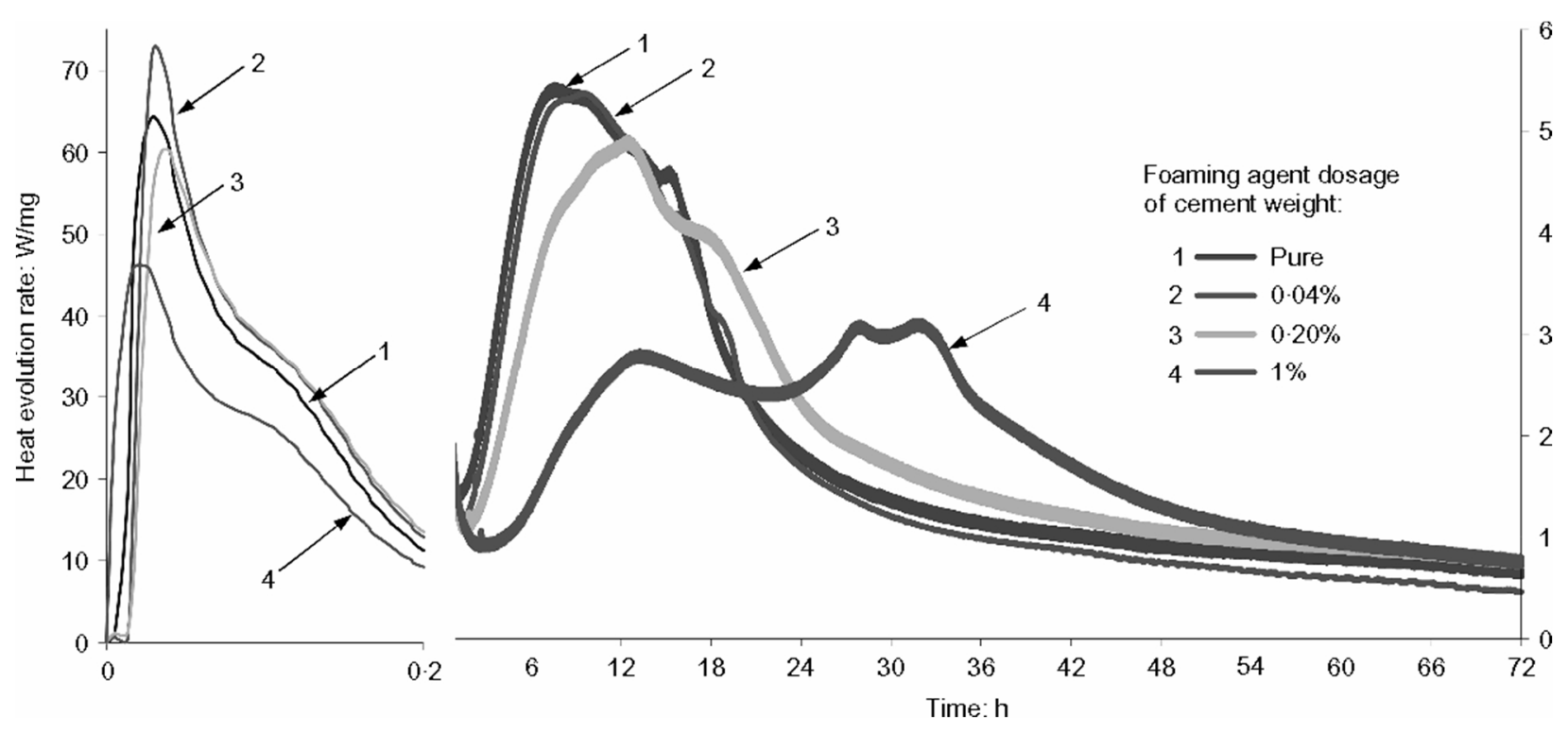

Figure 9. Kinetics of cement heat evolution with the presence of foaming agent addition

According to the results, the foaming agent addition affects both the magnitude and the rate of heat evolution. Within the first hour of cement and water interaction high heat evolution rates occur which are explained mostly by a wetting effect. Then, after a dormant period, the heat evolution rates increase again, reaching another peak value within 7 to $13 \mathrm{~h}$. The higher percentage of foaming agent has a greater impact on heat evolution rates. For the sample with $1 \%$ of foaming agent content (of the cement mass), the maximum rate reaches $2.8 \mathrm{~W} / \mathrm{mg}$, that is 1.75 times less than that of the control samples without foam addition. However, the integral amounts of generated heat are virtually the same for all the samples after a $72 \mathrm{~h}$ period of interaction and this constitutes about $435 \mathrm{~W} / \mathrm{mg}$ on average. 
The foaming agent additive both reduces the rate of heat evolution and delays the time taken to reach the maximum temperature. Most typical foamed concrete mix designs have foaming agent percentages between $0 \cdot 2$ and $0.7 \%$ of cement mass. Further research, such as testing plastic strength development of foamed concrete with different foaming agent content, should be conducted.

\section{Effect of density and cube size on temperature development}

The temperature profiles as shown in Figures 2,3,4 have been studied to establish the influence of the foamed concrete density on maximum temperatures that developed in the foamed concrete cores under semi-adiabatic hardening, in comparison with potential heat evolution due to cement hydration in totally isolated conditions.

Heat capacities of each foamed concrete mixture with silica sand as an aggregate were calculated. The total heat capacity of one cubic metre of foamed concrete is the sum of the heat capacities of all constituents. The volumetric heat capacity of the foamed concrete mix $\left(C_{\mathrm{v}}\right)$ can be calculated using Equation 3

$$
C_{\mathrm{v}}=\sum c_{i} m_{i}
$$

where $c_{i}$ is the specific mass heat capacities of components (cement, filler, water, foaming agent and the air taken from Table 2$)\left(\mathrm{J} /\left(\mathrm{kg}{ }^{\circ} \mathrm{C}\right)\right)$; and $m_{i}$ is the mass content of the ingredients in foamed concrete as it is prescribed in mix compositions in Table 2 and Table $3\left(\mathrm{~kg} / \mathrm{m}^{3}\right)$.

Thermal conductivity values for foamed concrete mixes $\left(\lambda_{\mathrm{v}}\right)$ have been calculated using Equation 4 , assuming that the material structure is uniform and the total value is determined from a volumetric contribution of each component in the given mix, considering thermal conductivity of cement and water as fresh cement paste that depends on initial water volume fraction, as reported by Bentz (2007).

$$
\lambda_{\mathrm{v}}=\sum \frac{\lambda_{l} m_{i}}{\rho_{i}}
$$

where $\lambda_{i}$ is the thermal conductivity of constituents (cement, filler, water, foaming agent and the air) as specified in Table $2(\mathrm{~W} /(\mathrm{mK})) ; m_{i}$ is the mass content of the relevant ingredient in the foamed concrete mix taken from Table 2 and Table $3\left(\mathrm{~kg} / \mathrm{m}^{3}\right)$; and $\rho_{i}$ is the real density of the corresponding constituent in the mix $\left(\mathrm{kg} / \mathrm{m}^{3}\right)$.

Calculations of heat capacity and thermal conductivity values of foamed concrete were done for the initial stage of hardening and results of the calculations are given in Table 4 . The values will change as water binds into hydrates having lower heat capacity values. The values are also prone to change as temperature increases with time owing to cement heat evolution (Bentz, 1998). These changes are complicated and warrant further investigations. 
Table 4. Calculated heat capacity and thermal conductivity of foamed concrete mixes, $300 \mathrm{~kg} / \mathrm{m}^{3} \mathrm{PC}$ content, silica sand fine aggregate

\begin{tabular}{|c|c|c|c|c|c|}
\hline \multirow[t]{2}{*}{ Characteristics } & \multirow[t]{2}{*}{ Unit } & \multicolumn{4}{|c|}{ Values for dry density grades } \\
\hline & & $350^{*}$ & 400 & 800 & 1200 \\
\hline Volumetric heat capacity, $C_{\mathrm{v}}$ & $\mathrm{kJ} /\left({ }^{\circ} \mathrm{C} \mathrm{m}^{3}\right)$ & $915 \cdot 70$ & $966 \cdot 90$ & $1479 \cdot 40$ & $1997 \cdot 80$ \\
\hline Thermal conductivity, $\lambda_{\mathrm{v}}$ & $\mathrm{W} /(\mathrm{m} \mathrm{K})$ & $0 \cdot 19$ & $0 \cdot 28$ & 0.53 & $0 \cdot 84$ \\
\hline
\end{tabular}

* Values valid for foamed concrete mix without aggregate.

In fully isolated conditions the heat resulting from cement hydration will be used only to heat the constituents. Based on the heat capacity equation the resultant temperature increment can be calculated showing the maximum possible temperature to be developed in foamed concrete. The total heat generated in a period of 3 days is determined as the product of cement content and integral value of specific heat evolution. The results of these calculations are presented in Figure 10.

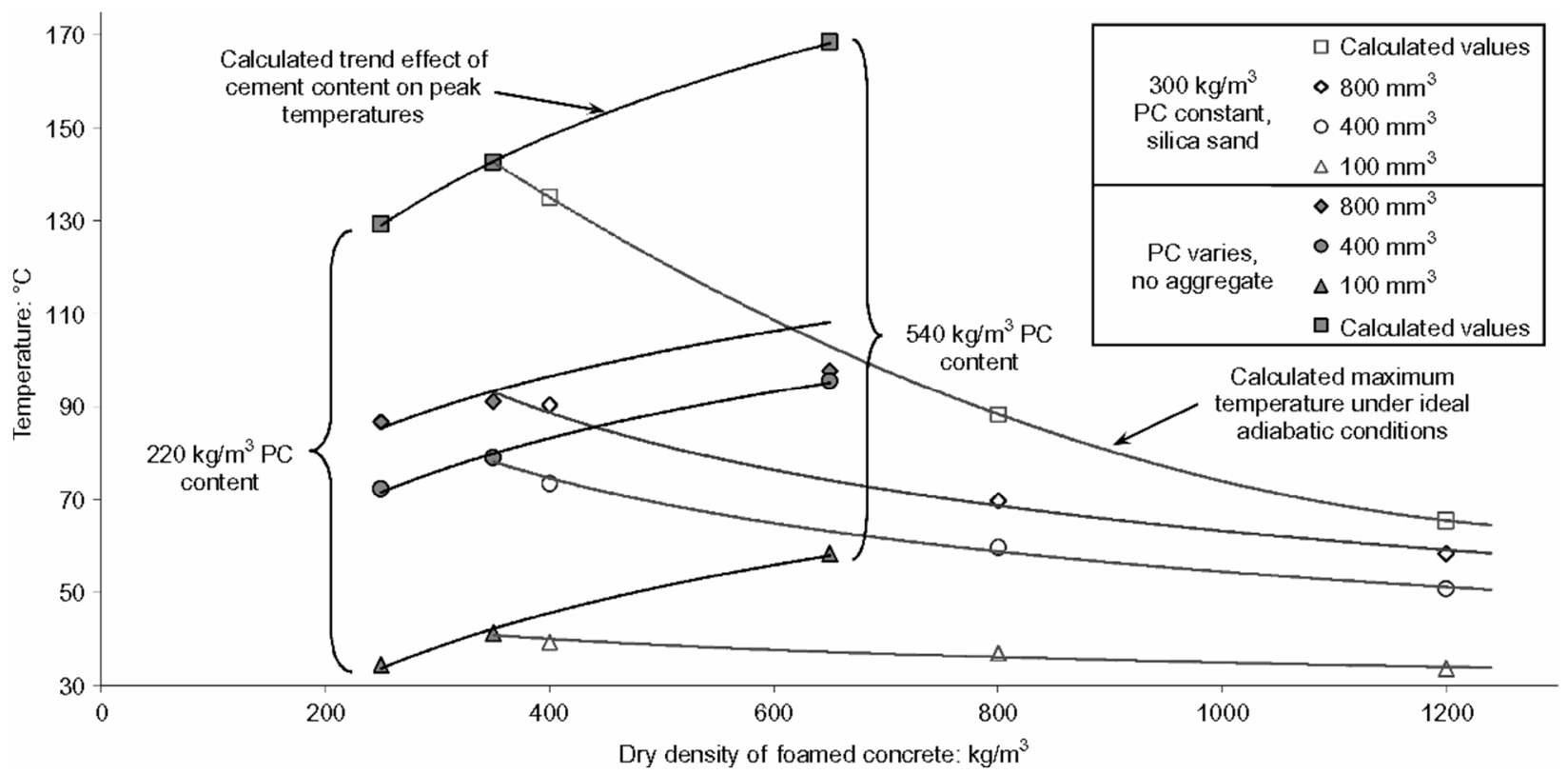

Figure 10. Influence of foamed concrete density on the maximum recorded temperature rise in comparison with calculated thermal maximums for foamed concrete under adiabatic conditions

It can be seen that the effect of foamed concrete density and pour size on maximum temperature in foamed concrete is more evident at lower foamed concrete density and larger volume of material (cement content being constant). However, the theoretical thermal potential is not reached by any of the mixes in the investigation. The difference between calculated and measured values indicates that truly adiabatic conditions did not exist. The thickness of the polystyrene layer will have to be increased significantly to ensure fully adiabatic conditions. 
For the given volume of foamed concrete pouring, the highest values of internal temperature would, therefore, be reached in foamed concrete of the lowest density that is practically achievable keeping cement content unchanged while meeting other product requirements (e.g. design compressive strength, non-collapsible structure, foamed concrete mix workability, etc.). Reducing cement content for the purpose of further decrease of foamed concrete density would inevitably result in decreased maximum temperature, as the generated heat is then mostly consumed by heat capacity or lost to the environment. The resulting heat is no longer enough to produce the same temperature effect.

\section{PREDICTION OF TEMPERATURE RISE IN FOAMED CONCRETE}

Foamed concrete, as any other building material, is produced under environmental conditions. Heat evolution is a spontaneous process that should be adjusted either to isothermal or adiabatic thermal conditions, not only to enable mathematical estimation and prediction of temperature development but also to minimise the influence of heat losses (Springenxchmid, 1998). However, even in laboratory conditions it was not possible to exclude heat losses. Owing to unexpectedly high temperature rise, the heat losses played a dominant role and resulted in reduced reliability of the recorded data.

Semi-adiabatic conditions resulted in extreme temperature development. It is believed that this can be a function of numerous parameters, the same as those for heat evolution described in the earlier section on 'Parameters influencing heat evolution in foamed concrete'. Taking into account all obvious factors that should have an impact on the maximum foamed concrete temperature in the current experimental programme, the following general function was derived

$$
T_{\max }=f\left[\mathrm{Cem},(\mathrm{Cem} / S), V, \rho_{\mathrm{v}}, C_{\mathrm{v}}, \lambda_{\mathrm{v}}, A\right]
$$

where $T_{\max }$ is the maximum registered temperature in a sealed box core of foamed concrete $\left({ }^{\circ} \mathrm{C}\right)$; Cem is the cement content in foamed concrete $\left(\mathrm{kg} / \mathrm{m}^{3}\right) ; S$ is the mass of all solid ingredients in the given foamed concrete mix $\left(\mathrm{kg} / \mathrm{m}^{3}\right) ; V$ is the volume of foamed concrete in a sealed box $\left(\mathrm{m}^{3}\right) ; \rho_{\mathrm{v}}$ is the casting density of foamed concrete $\left(\mathrm{kg} / \mathrm{m}^{3}\right) ; C_{\mathrm{v}}$ is the volumetric heat capacity of foamed concrete $\left(\mathrm{kJ} /\left(\mathrm{m}^{3}{ }^{\circ} \mathrm{C}\right)\right) ; \lambda_{\mathrm{v}}$ is the thermal conductivity coefficient of foamed concrete $\left(\mathrm{W} /\left(\mathrm{m}^{\circ} \mathrm{C}\right)\right)$; and $A$ is the overall surface area of foamed concrete cube in a sealed box $\left(\mathrm{m}^{2}\right)$.

Heat evolution is directly related to cement content in foamed concrete. Cement-to-solid ratio in the function considers the presence of inert fillers which are accumulators of evolved heat. The more filler there is in the solid phase, the lower is the maximum temperature. Volume of foamed concrete mass represents the influence of cube size on heat evolution. Foamed concrete density, heat conductivity and heat capacity are combined in a term of thermal diffusivity that describes the velocity of temperature change in the mass and it depends on the physical characteristics of the initial ingredients in the mix. Overall surface area is an indirect parameter of heat losses of foamed concrete masses, with higher surface area resulting in higher heat losses.

Multi-variable regression analysis was conducted to establish the effect of each of the identified parameters on the temperatures recorded. The best correlation was found for the following function

$$
T_{\max }=120 \cdot 29\left(\frac{a \mathrm{Cem}^{2} V^{2}}{S A^{2}}\right)^{0.17}
$$


where $a$ is the thermal diffusivity coefficient of foamed concrete $\left(\mathrm{m} / \mathrm{s}^{2}\right)$ using Equation 7

$$
a=\frac{\lambda_{\mathrm{v}}}{C_{\mathrm{v}} \rho_{\mathrm{v}}}
$$

Actual measured temperatures are compared to temperatures predicted using Equation 6, and this comparison is shown in Figure 11. The computed temperatures compare well with measured temperatures. The $R^{2}$ statistic indicates that the model as fitted explains $89 \cdot 3 \%$ of the variability in temperatures. More efficient heat insulation of moulds would probably give a still higher correlation. Although this function can only be used to predict temperatures under particular laboratory conditions, it does reflect the general trend indicating that the most dominant factors influencing temperature development are cement content and volume of pouring.

The prediction models proposed by many researchers (Alshamsi, 1994; Babitsky, 2005; Ballim, 2004; Bentz, 1998; De Schutter and Taerwe, 1995; Kearsley and Mostert, 2005a; Ross, 1949; Springenschmid, 1998; Zaporozhets et al., 1966)) were developed specifically for cement pastes or normal-weight concretes and neither thermal properties at lower densities of cellular concretes nor volume of casting were considered. An adjusted model needs to be developed to predict core temperatures in foamed concrete.

\section{CONCLUSIONS}

The experiments have shown that foamed concrete with dry densities ranging from D250 to D1200 experience high temperature development under semi-adiabatic conditions due to heat of cement hydration. The rate of temperature rise as well as maximum temperature reached are affected by numerous factors, the most important of these being cement content, plastic density and pour size of foamed concrete.

The investigations have shown that the highest temperature peaks are recorded for foamed concrete with the lowest possible density and large-sized moulds. The higher heat-insulating capacity of low-density foamed concretes helps to conserve the heat inside, initiating further acceleration of cement hydration. The inner layers of large masses are at almost adiabatic conditions; however, the heat still dissipates outwards. The pour size plays one of the dominant roles in temperature development and the size effect is more noticeable at lower foamed concrete densities.

There is an inverse relationship between the peak temperature under semi-adiabatic conditions and foamed concrete density with constant cement content.

The lowest thermal differences between core and surface of cubic moulds were recorded in the lowest density concrete and medium-sized moulds. In this case the temperature difference lies in the range 4-6 $6^{\circ}$, which should not result in problems with cracking. Heat-insulating foamed concretes (D400 and lower) are more efficient for applications in large pours. 


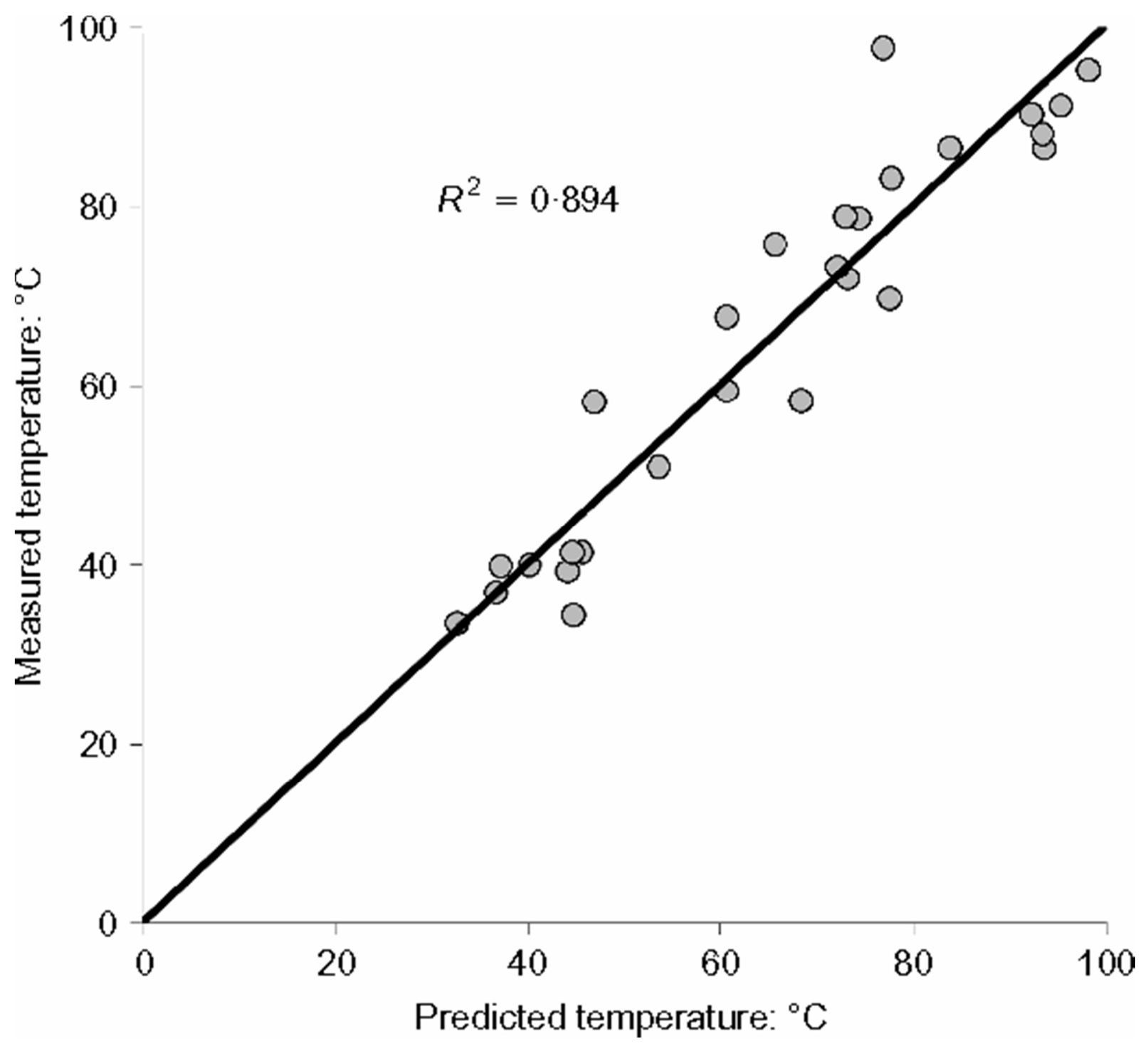

Figure 11. Measured temperature plotted against predicted temperature in the foamed concrete

Temperature rise in foamed concrete is directly related to cement content. Mix designs should therefore include as little cement as possible. This can be achieved by partial replacement with extenders, such as fly ash.

Existing hydration models should be carefully implemented to foamed concrete in order to take into account the main influencing aspects which are assumed to be negligible in normal concretes (e.g. thermal characteristics of the constituent materials and density).

Negative consequences of heat of hydration in foamed concrete should be taken into account when it is used in large volumes in order to prevent or to diminish mix settling, long-term strength losses, shrinkage, crack development and other problems. As test results showed, foamed concrete subjected to self-heating may experience porous structure collapse if temperatures reach $90^{\circ}$. However, the natural heat resulting from the exothermal reaction of cement hydration in foamed concrete should also be considered as a 
favourable factor speeding up curing. Further investigation is necessary to obtain prediction models for temperature development in foamed concrete of different shapes.

\section{ACKNOWLEDGEMENTS}

The authors would like to express appreciation for the research grants made by Duraset branch of the Aveng Group and the THRIP-program of the South African National Research Foundation to carry out the work reported in this paper.

\section{REFERENCES}

1. Aldridge D. Seminar Notes on Foamed Concrete: Properties, Applications and Potential. Scotland: University of Dundee; 2000. Foamed concrete for highway bridge works; p. 33-41.

2. Aldridge D. Introduction into foamed concrete: what, why, how?. Proceedings of an International Conference on Global Construction: Ultimate Concrete Opportunities, Dundee, Scotland; Thomas Telford; 2005. p. 1-4.

3. Alshamsi AM. Temperature rise inside pastes during hydration in hot climates. Cement and Concrete Research. 1994;24((2)):353-60.

4. Anikanova T. Heat-Insulating Foamed Concretes with Accelerated Setting. Technical Science Dissertation. Belgorod Shukhov State Technological University; 2007.

5. Atis CD. Heat evolution in high volume fly ash concrete. Cement and Concrete Research. 2002;32((5)):751-6.

6. Babitsky VV. The prognoses for the concrete hardening kinetics with the thermos processing of structures. Magazine of Construction Materials, Equipment and Technologies of XXIst Century. 2005;4((75)):66-7.

7. Ballim Y. A numerical model and associated calorimeter for predicting temperature profiles in mass concrete. Cement and Concrete Composites. 2004;26((6)):695-703.

8. Basuirski J, Wells D. The use of foamed concrete in construction and civil engineering. Conspectus. 2001:64-73.

9. Bentz DP. Prediction of adiabatic temperature rise in conventional and high-performance concretes using a 3-D microstructural model. Cement and Concrete Research. 1998;28((2)):28597.

10. Bentz DP. Transient plane source measurements of the thermal properties of hydrating cement pastes. Materials and Structures. 2007;40((10)):1073-80.

11. Cox L, Van Dijk S. Foam concrete for roof slopes and floor leveling. Concrete. 2003;37((2)):379.

12. De Schutter G, Taerwe L. General hydration model for Portland cement and blast furnace slag cement. Cement and Concrete Research. 1995;25((3)):593-604.

13. Giannakou A. Potential of foamed concrete to enhance the thermal performance of low-rise dwellings. Proceedings of the International Conference Concrete 2002: Innovations and Developments in Concrete Materials and Construction, University of Dundee, Scotland; Thomas Telford; 2002. p. 533-43.

14. Gosstandart. GOST 25485-89 Cellular concretes: Specifications. Russia: Gosstandart; 1990.

15. Jones MR, McCarthy A. Utilising unprocessed low-lime coal fly ash in foamed concrete. Fuel. 2005a;84((11)):1398-409.

16. Jones MR, McCarthy A. Behaviour and assessment of foamed concrete for fill and highway applications. Proceedings of an International Conference on Uses of Foamed Concrete Global Construction: Ultimate Concrete Opportunities, Dundee, Scotland; Thomas Telford; 2005b. p. 6188.

17. Jones MR, McCarthy A. Heat of hydration in foamed concrete: effect of mix constituents and plastic density. Cement and Concrete Research. 2006;36((6)):1032-41. 
18. Kearsley EP. The Effect of High Volumes of Ungraded Fly Ash on the Properties of Foamed Concrete. PhD thesis. UK: Leeds University; 1999.

19. Kearsley EP, Mostert HF. Designing mix compositions of foamed concrete with high fly ash contents. Proceedings of an International Conference on Uses of Foamed Concrete Global Construction: Ultimate Concrete Opportunities, Dundee, Scotland; Thomas Telford; 2005a. p. 2936.

20. Kearsley EP, Mostert HF. Opportunities for expanding the use of foamed concrete in the construction industry,. Proceedings of an International Conference on Uses of Foamed Concrete Global Construction: Ultimate Concrete Opportunities, Dundee, Scotland; Thomas Telford; 2005b. p. 143-54.

21. Kearsley EP, Wainwright PJ. The effect of high fly ash content on the compressive strength of foamed concrete. Cement and Concrete Research. 2001;31((1)):105-12.

22. Kim K-H, Jeon S-E, Kim J-K, Yang S. An experimental study on thermal conductivity of concrete. Cement and Concrete Composites. 2003;33((3)):363-71.

23. Kolomatskiy AS. Cement hardening processes in foam concrete. Proceedings of the International Conference Foamconcrete-2003, Belgorod; 2003. p. 108-16.

24. Langan BW, Weng K, Ward MA. Effect of silica fume and fly ash on heat of hydration of Portland cement. Cement and Concrete Research. 2002;32((7)):1045-57.

25. Malinina LA. Thermal Treatment of Heavy-weight Concrete. Moscow: Stroyizdat; 1977.

26. Ross AD. The prediction of temperatures in mass concrete by numerical computation. Magazine of Concrete Research. 1949;1((1)):9-21.

27. SABS (South African Bureau of Standards). SANS 50197-1:2000 Cement, Part 1: Composition, specifications and conformity criteria for common cements. South Africa: SABS Standard Division; 2002.

28. Sakharov GP. Non-autoclaved porous concrete and a problem of energy saving. Formula of Construction Journal. 2002;1((12)):20-1.

29. Shakhova LD. Production Enhancement of Non-Autoclaved Foamed Concrete with the Given Properties. PhD thesis. Belgorod: Belgorod Shukhov State Technological University; 2007. summary.

30. Springenschmid R. Prevention of Thermal Cracking in Concrete at Early Ages. New York, USA: RILEM R Technical Committee; 1998. Report 119-TCE.

31. Tarasov AS. The Increase in Foamed Concrete Effectiveness Owing to Internal Energy Potential. Belgorod Shukhov State Technological University; 2007.

32. Tarasov AS, Lesovik VS, Kolomatskiy AS. Industrial manufacture of foamed concrete products. Proceedings of the International Conference Poreconcrete-2005, Belgorod; 2005. p. 128-43.

33. Tisyachuk VV, Svinarev AV. Production and application of monolithic foamed concrete in construction. Proceedings of the International Scientific and Practical Conference Poreconcrete2005, Belgorod; 2005. p. 97-102.

34. Vasiljev VD, Lundyshev IA. Experience of monolithic foamed concrete use in construction. Proceedings of the International Conference Foamconcrete-2003, Belgorod; 2003 . p. 105-7.

35. Wimpenny DE. Some aspects of the design and production of foamed concrete. Appropriate concrete technology. In: Dhir RK, McCarthy MJ, editors. Proceedings of the International Conference on Concrete in the Service of Mankind; London: 1996. p. 245-54.

36. Zaporozhets ID, Okorokov SD, Pariyskiy AA. Heat Evolution of Concrete. Leningrad: Stroyizdat; 1966. 